UDC 811.111:378

DOI https://doi.org/10.32838/2663-6069/2020.4-1/31

Halahan Ya. V.

Yaroslav Mudryi National Law University

Ahibalova T. M.

National Technical University "Kharkiv Polytechnic Institute"

Karachova D. V.

National Technical University "Kharkiv Polytechnic Institute"

\title{
INTERCULTURAL SENSITIVITY \\ IN FOREIGN LANGUAGE ACQUISITION
}

The current paper is devoted to the intercultural approach to foreign language teaching at higher education institutions. The theoretical and methodological research, conducted in the context of a social cognitive perspective, is currently relevant and arises from the need to clarify an issue of effective learning as a means of integrating into a wider range of strategies, greater complexity of understanding, increased engagement, and self-direction. Developing concepts of themselves as interculturally sensitive language comprehenders, learners go through more positive emotions and affiliation to learning as well as tend to enhance action appropriate to the goals and context of education.

Communicative skills are measured through individual language performance that exists due to the cultural awareness of speech act functions (apologies, suggestions, complaints, refusals) and, at the same time, they appear to be an instrument for organizing other cultural domains. Graduates should be prepared for international interaction and cooperation, both at the language and professional level. Lack of foreign language experience that is a background for intercultural erudition, or judging another culture according to one's own values may lead to communication problems. To teach a foreign language taking into account more sense of students 'participation in their field-of-study knowledge community, it is necessary to create an environment of real communication for professional purposes: to organize scientific discussions in a foreign language on key themes, current problems, or research questions with the involvement of specialists in a particular field; to use field-specific terminology in the classroom via dialogues and monologues, wordplay; to use etymology reference literature on the origin and development of foreign professional words with the aim of enrichment of highly specialized terminology vocabulary.

Key words: linguoculturological approach, communicative skills, intercultural sensitivity, field-specific terminology, cultural awareness, term, vocabulary.

Defining the problem and argumentation of the topicality of the consideration. Globalization is changing education, culture, and economy. The modern world needs graduates who can perceive and interpret extremely fast, think creatively, and analyze. Students with a high level of foreign language mastery expand their horizon of knowledge, plunge into another linguistic universe, enrich their vocabulary, develop various types of memory (short-term, long-term, explicit, implicit, episodic, procedural), promote better mental abilities. Language awareness helps them to integrate into the foreign linguistic environment and become a part of another cultural society as soon as possible. The task of higher education institutions is to create an enabling environment for the formation and development of professional qualities of the student.
Interaction between foreign language teaching and intercultural sensitivity is evident. More and more students are becoming aware of the importance of understanding the research tools and theories used in intermentality communication. Moreover, the growth of multinational corporations and international investors in Ukraine has increased the possibility of intercultural mixes between specialists and clients. The topicality of the problem of relations between language and culture is one of the key issues in current linguistics. It is connected with the need for a theoretical understanding of the role of language in the process of intercultural communication. It is absolutely clear that language cannot exist without culture. Culture permeates all aspects of society, including the languages of people. On the other hand, 
when people need to share culture, they communicate through language. It is easy to conclude that people from different countries can understand each other when they speak different languages and have different worldviews because many basic concepts are universal and may be explained to foreigners.

Analysis of recent research and publications. It is widely known that language links our psychic and sociocultural life and at the same time, it is an instrument of their interaction. Potebnya stressed that language is not only the best but also the only sign by which we recognize people (Potebnya, 1993). Language, as a unique phenomenon of culture, has a significant impact on its development. The fundamental issues of the theory of intercultural communication were established by Aristotle, Leibniz, Boas, Hegel, Herder, Humboldt, Kant, and others long before it became a separate field of study. The theoretical ideas of abovementioned adept linguists were further interpreted by Charles Bally, Jan Baudouin de Courtenay, Leo Weisgerbert, Joseph Vandries, Jacob Grimm, A. A. Potebnya, Rasmus Rask, Heymann Steinthal, R. O. Jacobson, and others. The scientific works of these authors are the basis for a general theoretical approach to the complex study of the role of language in the process of intercultural communication. Within the current epoch of intercultural sensitivity investigation various authors offer overviews of the components that the notion of intercultural competence should contain (L. A. Arasaratnam, 2005; M. R. Hammer, 2003; D. K. Daerdorff, 2006; L. Parmenter, 2003; J. F. Greenholz, 2005; P. Koehn, 2002; M. Byram, 2003; N. Stone, 2006). In the stated works, variable aspects are under investigation taken in their complexity but flexibility, adaptability, empathy, respect, and communication skills are most frequently mentioned.

Setting the goals and tasks of the article. This paper aims at the analysis of scientific approaches and background to outline the main principles applied for a better understanding of intercultural effectiveness, as well as offers the range and peculiarities of methodological instruments so that teachers can facilitate relevant foreign language learning by university students.

The outline of the main research material. As language and culture are intertwined, language acquisition cannot be separated from cultural acquisition. Ronald Langacker [8, p. 16] described language as "an essential instrument and component of culture, whose reflection in linguistic structure is pervasive and quite significant". Similarly, George Lakoff and Mark Johnson [7, p. 69] remarked that cultural knowledge in the form of conventional images feeds into idioms based on metaphors. Moreover, complex categories are structured by experiential domains, which may be culture-specific [7, p. 95]. Language is a cultural activity and, at the same time, an instrument for organizing other cultural domains. Speakers take account of discourse situations, which are structured by culture. Paul Friedrich (1989) referred to this nexus of language and culture as linguaculture and Michael Agar (1994) called it linguaculture.

Kurtyka [6] pointed out that many teachers focus on culture as an important component of their instruction. Teachers are more effective if they stress the cultural basis of language. They may choose to introduce and highlight cultural models and take account of culture-specific models of learning itself [11]. Language, as a unique phenomenon of culture, has a significant impact on its development. It is hoped that more attention will be placed on researching and teaching intercultural communication skills for university students. To teach a foreign language as a means of communication, it is necessary to create an environment of real communication: to organize scientific discussions in a foreign language with the involvement of specialists in a particular field, to use special terminology in the classroom, to participate in international conferences, etc. The development of communication abilities is the main task faced by foreign language teachers. A higher school specialist should be prepared for international interaction and cooperation, both at the language and professional level.

On the one hand, specialists are enriched with knowledge and experience in the field of their professional activity, on the other hand, they should be able to establish contacts and transfer the accumulated experience and achievements of their country through intercultural communication. A highly qualified professional should not be limited to mere knowledge of the language. Therefore, the main purpose of international communication and contacts in the learning process is to prepare a future specialist who is ready to use the acquired knowledge and skills in the field of his/her communication. Problems may occur when a specialist, client or both, become ethnocentric. Ethnocentrism is defined as viewing the whole world only through one's own eyes with one's beliefs, values, and attitudes and not acknowledging that others may not see the world in the same way. The meaning intended by one person may not be correctly received by the other person. Developing an awareness of the possible impact ethnocentrism has on effective 
intercultural communication will be valuable to a graduate who deals with clients from backgrounds diverse from his or her own. Students should be able to identify their prejudices and learn to control them. These insights may help one to examine, analyze, predict, and regulate his or her conduct. This will help gain the best result by obtaining the most information from the client while avoiding any possible intercultural conflict. To understand communicators from different ethnic cultures within or outside their own country, future professionals should develop intercultural communication.

The downside of globalization is interpersonal, inter-group, and intercultural conflicts caused by a desire to preserve one's identity and unique culture, and language skills are a crucial component of intercultural communication. A specialist, who interacts with clients from different countries, and more specifically from different cultures, should consider establishing common ground and emphasizing similarities to help the client feel more comfortable in the exchange. Conveying to the client that the message was understood is probably even more important in an intercultural exchange than in an interview with a client from the same cultural background. They may actually be able to improve the client's satisfaction if his level of communication skills does not allow speaking with conviction.

Linguistic, information-cognitive, concrete practical and other tasks are used in educational and vocational acquisition. In an intercultural exchange, it may be difficult for a graduate to experience the feelings of a client whose cultural orientation has been different from his or her own. If, for instance, a professional decides that all Turkish clients are the same, he may not effectively empathize with the unique characteristics and feelings of a certain client. The key to empathy in an intercultural interaction is to prevent prejudices and stereotypes from clouding the graduate's perceptions of a culturally diverse client.

Accordingly, when a specialist and a client discuss a matter, they both send and receive messages through verbal and nonverbal cues. This communication process is ongoing and irreversible. We are always communicating, whether intentionally or not. When a businessman shuffles papers and looks at the clock, the client may get the message that it is time to go, whether or not the former intended such a message. In an intercultural exchange, several variables may cause breakdowns in the communication process. The solution for training tasks is widely associated with higher education. It can be successfully applied in the study of a foreign language, especially when a student has a double competence: learning a foreign language and at the same time acquiring expert knowledge in his degree subject.

Modern society needs not just specialists, but experts in intercultural communication. The magnitude of the problem of counseling clients from different cultures is increasing because specialists may spend thirty to eighty percent of their time counseling. Particularly in large cities, where multi-ethnic communities have burgeoned in the last twenty years, university graduates have many intercultural counseling situations. Therefore, higher education provides training specialists who are aware of the growing interconnection among countries, ready to participate in the dialogue of cultures. It should awake interest and respect for other cultures among students. This is the basis for successful communication. Effective cognition of foreign culture is impossible without learning a foreign language. Thus, knowledge of a foreign language is becoming one of the most effective means of communication, the condition of professional competence. Successful intercultural communication suggests cultural sensitivity, the ability to adequately interpret the communicative behavior of a representative of another society, readiness of communication participants to perceive other forms of communicative behavior, understanding their variations and cultural differences.

The originality of national and cultural standards is strongly felt in intercultural communication when a person faces an unexpected situation or the behavior of interlocutors. In intercultural exchanges, professionals and graduates must go beyond what the client says to discover what is actually meant. For example, there is a Japanese custom of speaking and acting only after due consideration has been given to the other person's feelings and points of view and a habit of not giving a clear-cut yes or no answer, a habit on a long tradition of avoiding unnecessary friction. In order to understand the reason and to master a cultural standard that is alien to one's own culture, it is necessary to find the answer to the question of why people of a different culture follow and respect such values. Intercultural learning ranges from linguistic, pragmatic (how to behave in a particular situation), aesthetic (what is considered beautiful or repulsive in another culture) to ethical (what are moral values) issues. It is necessary to study the world of native speakers, their culture, their way of life, peculiarities of their national character, mentality, because the real use of words in speech, the real reproduction of speech is largely determined by the knowledge 
of social and cultural life of natives. Many other variables may also cause problems in the intercultural exchange between graduates and clients. Nonverbal communication aspects such as differences in the use of personal space, and differences in the use and the value of time, are examples. Beliefs, attitudes, and values, and the world view of those involved are all other intercultural variables that might produce barriers affecting the intercultural exchange. Lack of accurate analysis of feedback may cause problems in communication. The curriculum should include social studies, speech etiquette, and rules of conduct. Cultural analyses and studies are also conducted.

Intercultural learning takes various forms through a variety of means. First, it can have different locations of learning: classrooms, museums, exhibitions, fieldwork, a short visit, an exchange program, independent learning. These locations form a continuum from structured learning to informal education. Intercultural sensitivity develops incrementally over time through learning in the classroom and, simultaneously, learning from the real world. Byram highlighted that "the real world" and "the classroom world" develop in parallel to each other [1].

The second important factor is the degree of direct contact. The experiential learning approach (also known as learning by doing) is based on the assumption that culture learning is best achieved when people have direct or simulated experiences, while a didactic approach assumes that cognitive understanding, which can be developed through traditional means such as lectures, reading and group discussion, is essential before individuals can effectively interact with people of another culture [5]. Thus, intercultural learning through participation in intercultural exchanges or study abroad programs can increase participants' knowledge of the host culture, improve fluency in the host country language, reduce anxiety in interacting with people from different cultures, develop sensitivity to cultural differences and increase efficacy. Participants also develop greater intercultural networks and friendships with people from different cultural backgrounds. The task is to get the right balance between challenge and support. The third factor is culture-specificity: whether and how much training is focused on one culture (culture-specific) or general principles regardless of cultures [4].

And the last element is the educational level. Postgraduate degrees in intercultural communication are offered by many universities and schools across theworld. Theyincorporateglobalcitizenship, aconcept closely related to intercultural communication, in their curriculum, modes of delivery: e.g. classroom- based learning, e-learning, work-based learning. The development of intercultural competence through education and training has emerged as a major theme in intercultural studies. Spencer-Oatey and Franklin provide a comprehensive overview of the field related to both professional and school-level educational contexts highlighting the challenges of incorporating intercultural competence into an already full curriculum [10, p. 199-241].

The first, as we see it, should be developing attitudes of openness and tolerance towards other people and cultures; providing information about daily life and routines; promoting reflection on cultural differences; providing information about shared values and beliefs; supporting experiences with a rich variety of cultural expressions (literature, theatre, film, etc.); maintaining the ability to handle intercultural contact situations; providing information about the history, geography and political conditions of the foreign cultures; promote the ability to empathize with people living in other cultures; promote increased understanding of students' own culture. In the beginning, it seems reasonable to discuss topics about daily life, and routines, living conditions, food and drink, traditions, folklore, tourist attractions, youth culture, educational, professional life, history, geography, political system, literature, values, and beliefs. Starting in the second semester of the academic year, international relations (political, economic, and cultural) with students' home country and other countries as well as professional vocabulary might be appropriate to be included in the curricula.

Conclusions and directions for further research in this area. To be effective in foreign language learning, we recommend using authentic materials given in the target language such as newspapers, magazines, books; to gain information on a different nation's world view from culturally-oriented texts and videos; to improve oral teachers' and students' input with the involvement of specialists in a particular field. Professional terminology translation poses special challenges to translators as those languages are "very much system-bound languages" [2]. Terms are created for particular systems and are closely related to the culture, values, and traditions of the nation. Their meaning is sometimes shaped by documents of the national state system. Term translation requires both a cognitive and communicative approach to the material, knowledge of the source and target systems, and assessment of the recipient, and the function of the target text. Some researchers [3] point out that different translation strategies should be used for lay readers and specialists, as well as for 
the texts used for information purposes and ones used as documents in the target language.

Noteworthy to say, lack of empathy, lack of trust, stereotyping, and especially ethnocentrism, or judging another culture according to one's own cultural values, may lead to intercommunication problems. Besides being a goal for further scrupulous analysis in terms of intercultural sensitivity, this attitude might lead to culturally diverse clients' negative reactions to specialists. Thus, by developing an awareness of all the aspects of intercultural communication, they may be able to reduce friction between themselves and clients of diverse cultural backgrounds and improve the service process.

\section{References:}

1. Byram, M. (1997). Teaching and assessing intercultural communicative competence. Clevedon: Multilingual matters.

2. De Groot, G.-R., van Laer, C. J. P. (2007). The Dubious Quality of Legal Dictionaries, Translation and Meaning. International Journal of Legal Information, 34 (1), pp. 65-86.

3. Friedrich, P. (1989). Language, ideology and political economy. American Anthropologist 91 (2), pp. 295-312.

4. Gudykunst, W., Hammer, M. R. (1983). Basic training design: Approaches to intercultural training. Landis D. and Brislin R. W. (eds). Handbook of Intercultural Training.Vol. 1: Issues in Theory and Design. New York: Pergamon Press, pp. 118-154.

5. Kolb, D. A. (1984). Experiential Learning: Experience as the Source of Learning and Development. Englewood Cliffs, NJ: Prentice-Hall.

6. Kurtyka, A. (2001). Teaching English phrasal verbs: A cognitive approach. Applied Cognitive Linguistics II: Language Pedagogy/ M. Pütz, S. Niemeier and R. Dirven (eds). Berlin/New York: Mouton de Gruyter, pp. 29-54.

7. Lakoff, G., Johnson, M. (1999). Philosophy in the Flesh: The Embodied Mind and Its Challenge to Western Thought. New York: Basic Books.

8. Langacker, R. (1999). "Assessing the cognitive linguistic enterprise". Cognitive Linguistics: Foundations, Scope, and Methodology / T. Janssen and G. Redeker (eds). Berlin/New York: Mouton de Gruyter, pp. 13-59.

9. Spencer-Oatey, H., Franklin, P. (2009). Intercultural interaction: a multidisciplinary approach to intercultural communication. Basingstoke: Palgrave Macmillan.

10. Strauss, C., D’Andrade R. G. (1992). Models and motives. Human Motives and Cultural Models. Cambridge: Cambridge University Press, pp. 1-21.

\section{Галаган Я. В., Агібалова Т. М., Карачова Д. С. МІЖКУЛЬТУРНА ЧУТЛИВІСТЬ У ПРОЦЕСІ ОВОЛОДІННЯ ІНОЗЕМНОЮ МОВОЮ}

Статтю присвячено дослідженню аспектології міжкультурного підходу в процесі викладання іноземних мов у вищих навчальних закладах. Теоретико-методологічна специифіка дослідження в соиіально-когнітивному контексті є наразі актуальною й викликана необхідністю визначення засад ефективного навчання, по-перше, як засобу інтеграчї в більш розвинутий спектр стратегічних навичок, по-друге, як мотиву для підвищення рівня зачікавленості мовия $і$ його самомотивації. Акиентовано, що, розвиваючи уявлення про себе як про культурно чутливих користувачів цілььвої мови, студенти переживають більше позитивних емоцій, відчувають прихильність до навчання, а також удосконалюють стратегію іншомовної поведінки, що відповідає цілям $і$ контексту сучасної освіти. 3'ясовано, щзо комунікативні навички вимірюють через індивідуальну мовну діяльність, яка існує завдяки усвідомленню мовием функцій мовленнєвих актів (вибачення, пропозиції, скарги, відмови), i водночас вони є інструментом організаиії інокультурних категорій $і$ символів. Випускники повинні бути готові до міжнародної взаємодії і співпрачі як на мовному, так і на професійному рівні, оскільки відсутність практики у використанні іноземних мов, яка є передумовою міжкультурної ерудиції, або оцінка іншої культури відповідно до власних иінностей може призвести до проблем у спілкуванні.

Доведено, що ефективності викладання іноземної мови з урахуванням важливості участі студентів у наукових і професійних спільнотах сприяє створення середовища реального спілкування іноземною мовою за фахом спеціалізації: організація дискусій іноземною мовою на актуальні теми, обговорення поточних проблем із залученням фахівців відповідної галузі; практика вживання специфічної галузевої термінології через діалоги та монологи, гру слів; задля збагачення словника вузькоспеціалізованої термінології залучення етимологічної літератури для пошуку інформачії щодо походження й розвитку іншомовної професійної лексики.

Ключові слова: лінгвокультурологічний підхід, комунікативні навички, міжкультурна чутливість, вузькогалузева термінологія, культурна обізнаність, термін, словник. 